\title{
Reliability of tests to determine peak aerobic power, anaerobic power and isokinetic muscle strength in children with spastic cerebral palsy.
}

Citation for published version (APA):

Berg-Emons, H. J. G., van Baak, M. A., de Barbanson, D. C., Speth, L., \& Saris, W. H. M. (1996).

Reliability of tests to determine peak aerobic power, anaerobic power and isokinetic muscle strength in children with spastic cerebral palsy. Developmental Medicine and Child Neurology, 38(12), 1117-1125. https://doi.org/10.1111/j.1469-8749.1996.tb15075.x

Document status and date:

Published: 01/01/1996

DOI:

10.1111/j.1469-8749.1996.tb15075.x

Document Version:

Publisher's PDF, also known as Version of record

Please check the document version of this publication:

- A submitted manuscript is the version of the article upon submission and before peer-review. There can be important differences between the submitted version and the official published version of record.

People interested in the research are advised to contact the author for the final version of the publication, or visit the DOI to the publisher's website.

- The final author version and the galley proof are versions of the publication after peer review.

- The final published version features the final layout of the paper including the volume, issue and page numbers.

Link to publication

\footnotetext{
General rights rights.

- You may freely distribute the URL identifying the publication in the public portal. please follow below link for the End User Agreement:

www.umlib.nl/taverne-license

Take down policy

If you believe that this document breaches copyright please contact us at:

repository@maastrichtuniversity.nl

providing details and we will investigate your claim.
}

Copyright and moral rights for the publications made accessible in the public portal are retained by the authors and/or other copyright owners and it is a condition of accessing publications that users recognise and abide by the legal requirements associated with these

- Users may download and print one copy of any publication from the public portal for the purpose of private study or research.

- You may not further distribute the material or use it for any profit-making activity or commercial gain

If the publication is distributed under the terms of Article 25fa of the Dutch Copyright Act, indicated by the "Taverne" license above, 


\section{RELIABILITY OF TESTS TO DETERMINE PEAK AEROBIC POWER, ANAEROBIC POWER AND ISOKINETIC MUSCLE STRENGTH IN CHILDREN WITH SPASTIC CEREBRAL PALSY}

Rita JG van den Berg-Emons

Marleen A van Baak

Donnie $C$ de Barbanson

Lucianne Speth

Wim HM Saris

Cerebral palsy (CP) is an inclusive term used to describe a number of chronic, non-progressive disorders of motor function that occur in young children as a result of disease of the brain (Ingram 1966). The most common form of CP is the spastic type, which accounts for approximately two-thirds to threequarters of all children with $\mathrm{CP}$ (Gamstorp 1985). Proneness to fatigue and low muscle strength are characteristic symptoms in CP (Brown 1975).

Monitoring the physical capacity of children with $\mathrm{CP}$ is of dual importance. On the one hand, it can yield information on the functional severity and natural history of the disease; on the other, it can help assess the effects of therapeutic interventions such as diet, physical therapy, occupational therapy or conditioning (Bar-Or 1986).

In the present study, the reliability of tests to determine peak aerobic power, anaerobic power and isokinetic muscle strength was established in young children with spastic CP. In addition, results found in the children with $\mathrm{CP}$ were compared with measurements in healthy controls.

\section{Subjects and method}

SUBJECTS

The total study group consisted of 12 children with spastic CP (six boys and six girls) and 39 healthy children (22 boys and 17 girls) between 6 and 12 years of age. The children with CP were classified according to the methods of Hagberg (Olow and Berg 1970) and Cruickshank (1966) by a physician at the Children's Rehabilitation Centre Franciscusoord in Valkenburg (Table I). Ten children with $\mathrm{CP}$ were classified as diplegic (legs and feet more affected than arms and hands); two were classified as tetraplegic (greater involvement of the upper part of the body than of the lower part). The children with $\mathrm{CP}$ were attending the elementary school at Franciscusoord (normal intelligence and mild mental retardation). The healthy children were recruited from an elementary school in Maastricht (normal intelligence). The children and their parents were informed of all aspects of the study and written consent was obtained. The study was approved by the Medical Ethical Committee of the University of Limburg and the Cooperating Rehabilitation Centres Limburg.

\section{ANTHROPOMETRIC MEASUREMENTS}

Body mass was obtained (Seca Germany) with the children wearing underclothing. For the children with CP a chair scale was used. Height measurements were taken while standing against a wall, or if unable to stand independently, while lying on a bed with a wooden $\mathrm{T}$-square or a flexible 
TABLE 1

Classification of the 12 children with CP

\begin{tabular}{|c|c|c|c|c|c|c|}
\hline \multirow[b]{2}{*}{ No. } & \multirow[b]{2}{*}{ Ser } & \multicolumn{3}{|c|}{$C P$ classification ${ }^{*}$} & \multirow[b]{2}{*}{ Severity ${ }^{+}$} & \multirow[b]{2}{*}{$\begin{array}{c}\text { Mode of } \\
\text { ambulation }\end{array}$} \\
\hline & & Tonus & $\begin{array}{l}\text { Abnormal } \\
\text { movements }\end{array}$ & Distribution & & \\
\hline 1 & $M$ & Hyper & - & Diplegia & 1 & Ambulant \\
\hline 2 & $M$ & Hyper & - & Diplegia & 1 & Ambulant \\
\hline 3 & $\mathrm{~F}$ & Hyper & - & Diplegia & 1 & Ambulant \\
\hline 4 & $\mathrm{M}$ & Hyper & - & Diplegia & 2 & Ambulant \\
\hline 5 & $\mathrm{~F}$ & Hyper & - & Diplegia & 1 & Ambulant \\
\hline 7 & $\mathrm{~F}$ & Hyper & Ataxia & Diplegia & 2 & Ambulant \\
\hline 8 & $M$ & Hyper & Alaxia & Diplegia & 2 & Ambulant \\
\hline 9 & $\mathrm{~F}$ & Hyper & - & Diplegia & 2 & Wheelchair \\
\hline 10 & $\mathrm{~F}$ & Hyper & - & Diplegia & 2 & Wheelchair \\
\hline 17 & $\mathrm{M}$ & Hyper & - & Tetraplegia & 3 & Wheelchair \\
\hline 23 & $M$ & Hyper & - & Diplegia & 2 & Ambulant \\
\hline 28 & $\mathrm{~F}$ & Hyper & Ataxia/athetosis & Tetraplegia & 3 & Wheelchair \\
\hline
\end{tabular}

*According to the classification of Hagberg (Olow and Berg 1970).

${ }^{+}$Gradation according to Cruickshank (1966): 1, may appear normal except that the precision of the movement may be impaired; 3, unable to care for all his bodily needs because he is unable to walk unassisted, talk clearly or has little use of his hands; 2, between 1 and 3.

tape. The thickness of four skinfolds (biceps, triceps, subscapular, supra-iliac) was measured with a Servier caliper on the non-dominant side of the body.

\section{PEAK AEROBIC POWER}

In the children with $\mathrm{CP}$, four progressive maximal aerobic exercise tests based on the McMaster All-Oul Progressive Continuous Cycling Test) (Bar-Or 1983) were performed on a mechanically braked Monark leg cycle ergometer. The first test was a habituation test, which was also used to check the protocol and find out whether the children with CP needed fixations on the pedals. This habituation test was followed by three 'real' tests within a period of three weeks. The healthy children performed two progressive maximal aerobic exereise tests within a period of three weeks. Resistance was increased every $2 \mathrm{~min}$ with a variable load, depending on the abilities of the child, until the child was unable to continue pedalling. Individual protocols were constructed such that the total exercise time ranged between $8 \mathrm{~min}$ and $12 \mathrm{~min}$. No fixed pedalling rate was required; the number of revolutions was recorded. All the tests were preceded by a wam-up of about 5 min and verbal encouragement was given throughout the the highest power output over the 2 min of a load. When the child could not complete 2 minutes of the final load, peak power was calculated as the mean of the power of the penultimate stage and the final stage. Peak heart rate (HR, measured with a Sport Tester PE3000, Polar Electro, Finland) was delined as the highest average HR over the last minute of a load.

\section{ANAEROBIC POWER}

Anaerobic performance was measured by the Wingate Anaerobic Cycling Test (WAnT). A detailed description of this test can be found elsewhere (Dotan and Bar-Or 1980, Bar-Or 1987). Briefly, the WAnT is a 30 s cycling test at all-oul speed, against a constant braking force. The children with $C P$ performed the WAnT lour times on the mechanically braked Monark leg cycle ergometer. The first test was a practice session. By trial and error the foree was determined that elicited the highest power (=optimal braking force). Subsequently, three tests were perlormed on each child with CP, within a period of three weeks, using this predetermined force setting. In the healthy children, two tests were performed during a time span of three weeks. All the tests were preceded by a warm-up of aboul $5 \mathrm{~min}$ and verbal 
TABLE II

Classification of the 12 children with $C P$ and the 39 healthy children

\begin{tabular}{|c|c|c|c|c|c|c|}
\hline & $N$ & $\begin{array}{l}\text { Age } \\
\text { (yrs) }\end{array}$ & $\begin{array}{l}\text { Height } \\
(\mathrm{cm})\end{array}$ & $\begin{array}{c}\text { Mass } \\
(\mathrm{kg})\end{array}$ & $\begin{array}{l}\text { Sum four } \\
\text { skinfolds } \\
\text { (mm) })\end{array}$ & $\begin{array}{c}B M l^{l} \\
\left(\mathrm{~kg} / \mathrm{m}^{2}\right)\end{array}$ \\
\hline CP $\mathrm{M}$ & 6 & $\begin{array}{c}8.2 \pm 1.5 \\
(7-11)\end{array}$ & $\begin{array}{c}128.8 \pm 10.3 \\
(121.0-151.0)\end{array}$ & $\begin{array}{l}30.4 \pm 12.5 \\
(20.0-57.0)\end{array}$ & $\begin{array}{l}30.0 \pm 14.6 \\
(14.0-58.0)\end{array}$ & $\begin{array}{c}17.6 \pm 3.8 \\
(13.7-25.0)\end{array}$ \\
\hline $\mathrm{CP} \quad \mathrm{F}$ & 6 & $\begin{array}{c}9.3 \pm 1.8 \\
(7-12)\end{array}$ & $\begin{array}{c}134.4 \pm 12.7 \\
(120.0-152.5)\end{array}$ & $\begin{array}{l}35.1 \pm 16.3 \\
(19.0-68.0)\end{array}$ & $\begin{array}{l}36.0 \pm 17.5 \\
(23.0-70.0)\end{array}$ & $\begin{array}{c}18.5 \pm 5.3 \\
(13.2-29.2)\end{array}$ \\
\hline Healthy M & 22 & $\begin{array}{c}9.0 \pm 2.2 \\
(6-12)\end{array}$ & $\begin{array}{c}138.0 \pm 12.9 \\
(116.5-160.0)\end{array}$ & $\begin{array}{c}33.6 \pm 9.1 \\
(21.0-57.0)\end{array}$ & $\begin{array}{c}22.5 \pm 4.2 \\
(15.0-32.0) \\
*\end{array}$ & $\begin{array}{c}17.3 \pm 1.8 \\
(14.8-22.3)\end{array}$ \\
\hline Healthy $F$ & 17 & $\begin{array}{c}9.5 \pm 1.9 \\
(6-12)\end{array}$ & $\begin{array}{c}141.3 \pm 11.6 \\
(124.5-166.5)\end{array}$ & $\begin{array}{c}36.1 \pm 7.7 \\
(25.0-52.0)\end{array}$ & $\begin{array}{c}31.2 \pm 8.0 \\
(16.0-44.0)\end{array}$ & $\begin{array}{c}17.8 \pm 1.5 \\
(14.7-20.4)\end{array}$ \\
\hline
\end{tabular}

Values are means $\pm S D$, with ranges in parentheses.

'BMI: body mass index; * $p<0.001$.

encouragement was given throughout the 30 s period. Pedal revolutions were registered continuously. Two performance indices were calculated: peak power (PP, reflecting the ability of the limb muscles to produce high mechanical power in a short time) and mean power (MP, reflecting the ability to sustain high power) (Bar-Or 1987).

\section{ISOKINETIC MUSCLE STRENGTH}

Muscle strength was determined by an isokinetic device (Cybex II, Ronkonkoma, NY, USA), recording strength as torque in Nm. Details concerning the principles of isokinetic exercise may be found elsewhere (Hislop and Perrine 1967, Thistle et al. 1967). Torque determinations were made on the extensor and flexor muscles of the knees at three different angle speeds $(30 \% \mathrm{~s}, 60 \%$, $120 \% \mathrm{~s}$ ). The test was conducted while the child was seated in an erect position with thigh and pelvis stabilized. All measurements were performed at the damping levels recommended by the Cybex Testing Manual (1983). After two trial motions at each speed to familiarize the subject with the testing apparatus, each subject performed five maximal contractions, starting with the least affected/dominant leg (children with $\mathrm{CP}$ and healthy children, respectively) at the different speeds (test 1). Each subject started at an angular velocity of $30 \%$ and had brief rest intervals between the different speeds. Verbal encouragement was given to exert maximal effort. After repositioning the apparatus, the subject completed the above procedures for the opposite limb. The reliability of the test (within-day reliability) was established by repeating the protocol after a rest period of about $1.5 \mathrm{~h}$ (test 2). Peak torque (PT) was defined as the maximum torque generated by the subject throughout one series of repetitions.

The healthy children performed the aerobic and anaerobic cycle test on the same day (with a sulficient break between the (wo tests); cycle tests in the children with $\mathrm{CP}$ were on separate days. Isokinetic strength tests were in both groups of children on separate days. For practical reasons, the numbers of children differed between the three physical capacity tests.

\section{STATISTICAL ANALYSIS}

Data are presented as means $\pm S D$. Comparisons between data were made with the Friedman test ( $k$ related samples) and the Wilcoxon test (two related samples) for paired observations and the MannWhitney U test for unpaired observations $(\alpha=0.05)$. Test-retest reliability was established by Spearman's rank order correlation $\left(r_{\mathrm{s}}\right)$. Because of different ranges in test outcome between the children with $\mathrm{CP}$ and the healthy 


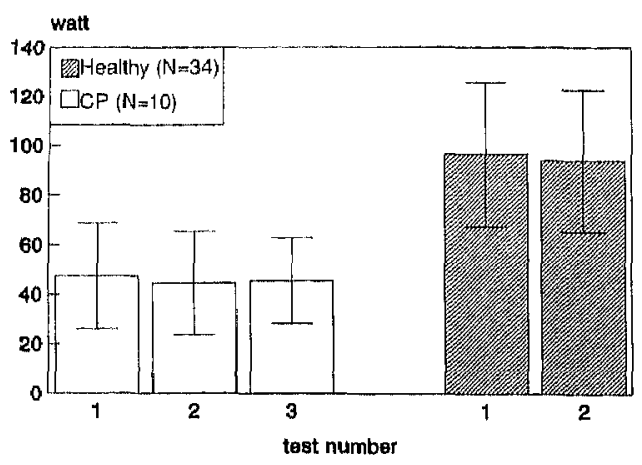

test 1 vs 2 CP: $r_{s}=0.92(\rho<0.001)$ Healthy: $r_{s}=0.90(p<0.001)$

test 2 vs 3 CP: $r_{s}=0.72(p<0.001)$

test 1 vs 3 CP: $r_{s}=0.84(p<0.001)$

Fig. 1. Peak aerobic power (W) during differeit tests in 10 children with spastic $C P$ and 34 healthy children.

children, the intra-individual difference between tests was calculated as a percentage of the mean individual test outcome.

\section{Results}

Characteristics of the children with $\mathrm{CP}$ and the healthy group are presented in Table II. None of the differences in characteristics between the children with CP and the healthy group was statistically significant. The healthy girls had a significantly higher $(p<0.001)$ sum of four skinfolds than the healthy boys, whereas the difference between the boys with CP and girls with CP was not statistically signilicant.

\section{PEAK AEROBIC POWER}

Peak aerobic power in the children with CP (six boys, four girls; eight diplegic, two tetraplegic) and in the healthy children ( 22 boys and 12 girls) did not differ significantly between the tests (Fig. 1). Test-retest correlation coefficients for peak aerobic power between the first and second test were similar in the children with CP and healthy children. However, the intra-individual difference (as a percentage of the mean power; absolute intra-individual differences were similar in the two groups) between the first and second test was significantly higher $(p<0.05)$ in the children with CP $(19.1 \pm$ $11.8 \%)$ than in the healthy children $(9.9 \pm$ $7.4 \%$ ). Intra-individual differences between tests one and three and between tests two and three in the group with CP, did not differ from the intra-individual difference between the first and second tests.

Spearman's correlation between body mass and peak aerobic power was 0.73 $(p<0.01)$ in the group with CP and 0.83 $(p<0.001)$ in the healthy group. Peak aerobic power $(\mathrm{W} / \mathrm{kg})$ was on average $46 \%$ lower $(p<0.001)$ in the children with $\mathrm{CP}$ $(1.5 \pm 0.5 \mathrm{~W} / \mathrm{kg})$ than in the healthy children $(2.8 \pm 0.4 \mathrm{~W} / \mathrm{kg})$. In three children with CP (numbers 1, 2 and 4; Table I), peak aerobic power per $\mathrm{kg}$ was within the range found in their healthy peers.

Peak HR almost always occurred in the final load of a test. Peak HR in the children with CP was $168 \pm 15 \mathrm{bpm}$ in the first test, $167 \pm 14 \mathrm{bpm}$ in the second test and $164 \pm 13 \mathrm{bpm}$ in the third test. Differences in peak HR between the tests were not statistically significant. Peak HR in the children with CP was on average $13 \%$ lower $(p<0.001)$ than in the healthy children. Peak HR in the healthy children did not differ between the two tests $(191 \pm 12 \mathrm{bpm}$ in the first test and $190 \pm 13 \mathrm{bpm}$ in the second test).

\section{ANAEROBIC POWER}

PP in the children with CP (six boys, six girls; 10 diplegic, two tetraplegic) tended to increase from the first to the third test (Fig. 2). This increase of $14 \%$ was, however, not statistically significant $(p=0.08)$. MP in the group with $\mathrm{CP}$ did not differ significantly between the tests. In the healthy children ( 22 boys and 12 girls), there were no statistically significant differences in PP and MP between the two tests (Fig. 3). Test-retest correlation coefficients for PP and MP were similar in both groups of children (Figs. 2, 3). Mean intra-individual differences in PP and MP (as a percentage of the mean power; absolute intra-individual differences tended to be higher (ns) in the healthy group) between the first and second test were $14.2 \pm 13.4 \%(\mathrm{CP})$ and 6.8 $\pm 8.0 \%$ (healthy) for $\mathrm{PP}$ and $12.3 \pm 12.1 \%$ (CP) and $9.7 \pm 7.2 \%$ (healthy) for MP $(n s)$. Intra-individual differences between tests one and three and between tests two and three in the group with CP did not differ from the intra-individual differences between the first and second tests. 
Spearman's correlations between body mass and anaerobic performance were $0.73(p<0.001)$ in the children with CP and $0.79(p<0.001)$ in the healthy children. PP $(\mathrm{W} / \mathrm{kg})$ was on average $55 \%$ lower $(p<0.001)$ in the children with $\mathrm{CP}$ $(3.0 \pm 1.3 \mathrm{~W} / \mathrm{kg})$ than in the healthy children $(6.6 \pm 1.0 \mathrm{~W} / \mathrm{kg})$. MP $(\mathrm{W} / \mathrm{kg})$ was on average 50\% lower $(p<0.001)$ in the children with CP $(2.3 \pm 0.9 \mathrm{~W} / \mathrm{kg})$ than in the healthy children $(4.6 \pm 0.7 \mathrm{~W} / \mathrm{kg})$. Anaerobic performance was in only two children with CP (numbers 1 and 4; Table I) within the range found in their healthy peers.

\section{ISOKINETIC MUSCLE STRENGTH}

In Table III, flexion and extension PT $(\mathrm{Nm})$, test-retest correlation coefficients and intra-individual differences (as a percentage of mean PT), are presented for the different speeds during the two tests. The isokinetic strength test could not be performed in four children of the group with CP because muscle strength was too weak. In the children with $\mathrm{CP}$ (five boys, three girls; all diplegic), there were no significant differences in flexion and extension PT between the two tests. In the healthy children (21 boys, 17 girls), flexion and extension PT at $30 \%$ and flexion PT at $60 \%$ s were in the second test lower (on average $4 \%, p<0.05$ ) than in the first test. Test-retest correlation coefficients were at all speeds lower in the group with $\mathrm{CP}$ than in the healthy group. Intra-individual differences (as a percentage of the mean PT; absolute intra-individual differences were similar in both groups) were significantly higher $(p<0.01)$ in the group with $\mathrm{CP}$ than in the healthy group at $60 \%$ s (flexion) and at $120 \%$ s (flexion and extension).

At $30 \%$ and $60 \%$, PT in the group with $\mathrm{CP}$ was on average $25 \% \quad(p<0.05)$ higher in the less affected leg than in the more affected leg. At $120 \%$ s there was no significant difference between legs. In the healthy children, comparisons between dominant and non-dominant leg yielded no consistent results.

Because higher correlations were found between height and PT (CP: mean $r_{\mathrm{s}}$ over the different speeds $=0.53 \pm 0.06$; healthy: mean $r_{\mathrm{s}}=0.89 \pm 0.03$ ) than between weight and PT (CP: mean $r_{\mathrm{s}}=$

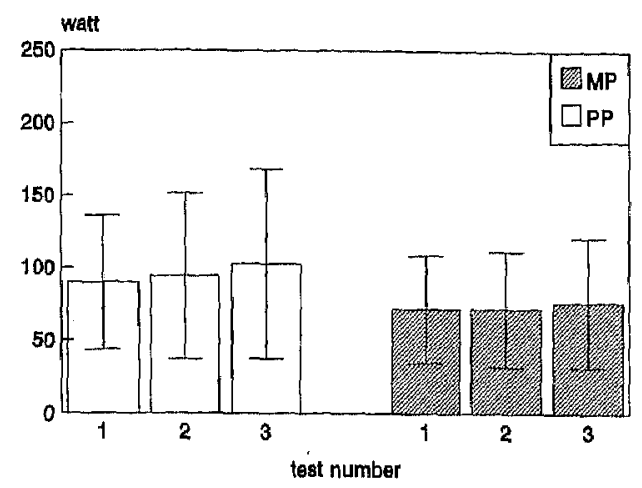

test 1 vs 2 PP: $r_{s}=0.90$ ( $\left.p<0.001\right)$ MP: $r_{5}=0.95(p<0.001)$ lest 2 vs 3 PP: $r_{5}=0.90(0<0.001)$ MP: $r_{5}=0.92(0<0.001)$ test 1 vs 3 PP: $r_{s}=0.94$ (p<0.001) MP: $r_{s}=0.95(0<0.001)$

Fig. 2. Peak anaerobic power (PP; W) and mean anaerobic power $(M P$; W) during three tests in 12 children with spastic CP.

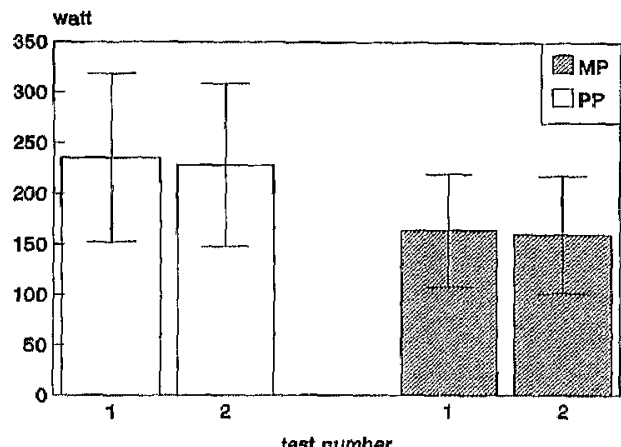

test 1 vs 2 PP: $r_{b}=0.96$ (p<0.001) MP: $r_{\mathrm{s}}=0.92$ (p<0.001)

Fig. 3. Peak anaerobic power (PP; W) and mean anaerobic power (MP; W) during two tests in 34 healthy chilatren.

$0.46 \pm 0.07$; healthy: mean $r_{\mathrm{s}}=0.83 \pm$ $0.03)$, PT data between the children with $\mathrm{CP}$ and the healthy group were compared when expressed per cm body height. Flexion and extension $\mathrm{PT} / \mathrm{cm}$ were on average (over the three test velocities) $53 \%$ and $48 \% \quad(p<0.001)$ lower in the children with CP than in the healthy children respectively. Only two children with CP (numbers 2 and 4; Table I), had PT values within the range of their healthy peers.

\section{Discussion}

In comparison with representative samples of the Dutch population of the same age (Roede and van Wieringen 1985), the 
TABLE III

Mean scores (SD) of knee flexion and extension peak torque, test-retest correlation coefficients $\left(r_{s}\right)$ and intra-individual difference during two tests in eight children with $\mathrm{CP}$ and 38 healthy children

\begin{tabular}{|c|c|c|c|c|c|c|c|c|c|}
\hline & $\begin{array}{c}\text { speed } \\
(\%)\end{array}$ & $\begin{array}{l}\text { Flexion } \\
\text { Test I } \\
(N m)\end{array}$ & $\begin{array}{l}\text { Test } 2 \\
(N \mathrm{~m})\end{array}$ & $r_{s}$ & $\begin{array}{l}I D^{\prime} \\
(\%)\end{array}$ & $\begin{array}{c}\text { Extension } \\
\text { Test } 1 \\
(N m)\end{array}$ & $\begin{array}{l}\text { Test } 2 \\
(N \mathrm{~m})\end{array}$ & $r_{s}$ & $\begin{array}{l}I D \\
(\%)\end{array}$ \\
\hline \multirow[t]{3}{*}{$\mathrm{CP}$} & 30 & $\begin{array}{l}23.7 \\
(9.1)\end{array}$ & $\begin{array}{c}21.9 \\
(10.0)\end{array}$ & $0.84 *$ & $\begin{array}{c}25.1 \\
(26.7)\end{array}$ & $\begin{array}{c}41.3 \\
(15.7)\end{array}$ & $\begin{array}{c}39.5 \\
(16.7)\end{array}$ & $0.71 * *$ & $\begin{array}{c}25.3 \\
(25.3)\end{array}$ \\
\hline & 60 & $\begin{array}{c}21.2 \\
(10.1)\end{array}$ & $\begin{array}{l}20.2 \\
(8.8)\end{array}$ & $0.75^{*}$ & $\begin{array}{c}29.9 \\
(20.0)\end{array}$ & $\begin{array}{c}39.4 \\
(19.5)\end{array}$ & $\begin{array}{c}39.8 \\
(17.4)\end{array}$ & 0.55 & $\begin{array}{r}29.6 \\
(24.9)\end{array}$ \\
\hline & 120 & $\begin{array}{r}18.3 \\
(8.2)\end{array}$ & $\begin{array}{l}19.0 \\
(7.8)\end{array}$ & $\begin{array}{l}0.65^{* *} \\
(27.4)\end{array}$ & 32.1 & $\begin{array}{l}27.1 \\
(9.7)\end{array}$ & $\begin{array}{c}30.8 \\
(12.8)\end{array}$ & 0.42 & $\begin{array}{c}33.8 \\
(27.6)\end{array}$ \\
\hline \multirow[t]{3}{*}{ Healthy } & $\begin{array}{l}y \\
y 0\end{array}$ & $\begin{array}{c}49.6 \\
(20.5)\end{array}$ & ***** $\begin{array}{c}47.1 \\
(19.1)\end{array}$ & $0.88 *$ & $\begin{array}{c}14.7 \\
(13.9)\end{array}$ & $\begin{array}{c}75.4 \\
(32.7)\end{array}$ & 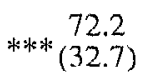 & $0.95 *$ & $\begin{array}{l}11.6 \\
(9.2)\end{array}$ \\
\hline & 60 & $\begin{array}{c}47.1 \\
(19.2)\end{array}$ & ***** $\begin{array}{c}45.3 \\
(19.2)\end{array}$ & $0.90^{*}$ & $\begin{array}{c}12.5 \\
(11.5)\end{array}$ & $\begin{array}{c}73.6 \\
(29.2)\end{array}$ & $\begin{array}{c}70.9 \\
(31.9)\end{array}$ & $0.90^{*}$ & $\begin{array}{c}17.1 \\
(14.2)\end{array}$ \\
\hline & 120 & $\begin{array}{c}44.4 \\
(19.3)\end{array}$ & $\begin{array}{c}43.3 \\
(18.7)\end{array}$ & $0.91^{*}$ & $\begin{array}{c}15.9 \\
(14.9)\end{array}$ & $\begin{array}{c}59.8 \\
(24.6)\end{array}$ & $\begin{array}{c}58.2 \\
(24.0)\end{array}$ & $0.92^{*}$ & $\begin{array}{r}12.7 \\
(12.7)\end{array}$ \\
\hline
\end{tabular}

ID $=$ intra-individual difference, $* p<0.001, * * p<0.05, * * * * 00.05 . \mathrm{N}=7$.

For llexion at $60 \%$ and $120 \%$, and extension at $120 \%$ s: ID is significantly different $(p<0.01)$

between the group with $\mathrm{CP}$ and the healthy group.

healthy children were on average heavy for their height (boys on average $3 \mathrm{~kg}$ heavier than the mean weight for height; girls $4 \mathrm{~kg}$ heavier). The healthy girls were also tall for their age (on average $3 \mathrm{~cm}$ taller than standards of attained height in Dutch children). The children with $\mathrm{CP}$ were, in comparison with the Dutch reference data (Roede and van Wieringen 1985), small for their age (boys on average $2 \mathrm{~cm}$ shorter than reference data; girls on average $4 \mathrm{~cm}$ shorter) and heavy for their height (boys on average $5 \mathrm{~kg}$ heavier, girls $7 \mathrm{~kg}$ heavier than the mean weight for height of Dutch children). The short stature of the children with CP is in conformity with previously published reports (Tobis et al. 1961, Ruby and Matheny 1962). The large weight for height in the children with $C P$ was also found in the study of Berg and Isaksson (1970) in severely handicapped children with CP.

\section{PEAK AEROBIC POWER}

The results obtained during the different tests suggest that, both in the children peak aerobic power tests are reliable. Absolute values of peak aerobic power of the healthy children of the present study are in agreement with cycle ergometry studies as presented by Bar-Or (1983) and Washington et al. (1988). When expressed per $\mathrm{kg}$ body mass, the peak aerobic power of the healthy children of the present study was about $20 \%$ lower, but this was probably due to the relatively high body mass in the present study. The children with CP had on average only about $50 \%$ of the aerobic power (in absolute terms and per $\mathrm{kg}$ body mass) of the healthy children. This subnormal aerobic power in CP is in agreement with previous reports (Lundberg 1978, 1984; Dresen et al. 1982; Bar-Or 1983, 1986).

The significantly lower peak HR in the children with $C P$ than in the healthy children suggests that peak aerobic performance during leg cycling was attained at a lower level of cardiorespiratory stress in the group with CP than in the healthy group. Apparently, acrobic exercise testing by means of cycle ergometry in these children is restricted by noncardiorespirtory factors. 
ANAEROBIC POWER

PP (in absolute units) in the healthy children was in good agreement with studies in healthy children in Canada and Israel (Bar-Or 1983). MP was, in comparison with those studies, on average about 15 to $20 \%$ lower (particularly in the boys). When expressed per $\mathrm{kg}$ body mass, PP and MP were about $8 \%$ and $23 \%$ lower, respectively, than the data of $\mathrm{Bar}-\mathrm{Or}$ (1983), but this can partly be explained by the relatively high body mass in the present study. Anaerobic performance in the children with $\mathrm{CP}$ was distinctly subnormal when compared with the healthy children, which is in agreement with the study of Parker et al. (1992).

The high test-retest correlation coefficients found in the present study indicate that the WAnT is highly reliable in groups of young children with $\mathrm{CP}$ and young healthy children. This is in agreement with studies in healthy subjects, patients with chronic obstructive lung disease and patients with neuromuscular disease, including children with spastic CP (Bar-Or 1987, Tirosh et al. 1990). PP showed a tendency to increase with repeated testing in the children with CP, an effect that was not seen in the healthy group. Although the increase did not reach statistical significance $(p=0.08)$, the possibility of a gradual increase in PP with repeated testing over a short time cannot be excluded.

\section{ISOKINETIC MUSCLE STRENGTH}

PT measurements at $30 \%$ in the healthy children of the present study showed good agreement with previously reported results in healthy children of the same age in the USA (Gilliam et al. 1979). Results at $120 \%$ were about 10 to $15 \%$ higher in the present study. To oul knowledge there is no literature available on PT of the knee flexors and extensors at $60 \% \mathrm{~s}$ in healthy children, nor on PT measurements in young children with spastic CP. Similar to the results we found on aerobic and anaerobic power, PT in the children with $\mathrm{CP}$ is extremely low when compared with their healthy peers.

From studies of Alexander and Molnat (1973) and Molnat et al. (1979), it can be concluded that, in young children ( 7 to 15 years) with normal intelligence and mild mental retardation, isokinetic muscle strength testing is a reliable and reproducible technique. The results from the healthy children in the present study confirm this high reliability of isokinetic strength testing. However, the data from our study cannot quite be compared with the studies of Alexander and Molnar, because they established the test-retest reliability on different days, whereas in the present study the within-day reliabilty was assessed.

In the children with CP, extension PT cannot be measured reliably at higher test velocities $\left(60^{\circ} / \mathrm{s}\right.$ and $\left.120 \% \mathrm{~s}\right)$. A possible explanation for this could be that the coordination of agonist and antagonist muscles is more impaired at higher velocities than at lower velocities (this could also explain the lack of difference in PT between less affected and more affected leg at $120 \% \mathrm{~s})$. However, when the test velocity of $30^{\circ} / \mathrm{s}$ is used, isokinetic strength testing seems to provide an objective, sale (muscles cannot be overloaded) and reliable method to determine the torque-generating capabilites in groups of young children with spastic $\mathrm{CP}$.

\section{Conclusion}

The results of the present study indicate that, as in healthy clildren, peak aerobic power, anaerobic power, and isokinetic muscle strength (at $30 \%$ ), can be measured reliably in groups of young children with spastic CP. The higher intra-individual differences in the group with CP than in the healthy group suggest that, at an individual level, the tests are less suitable for children with CP than in their healthy peers (possibly because of attention deficits, which are known to occur in CP (Binder and Eng 1989)). These findings have important implications for the use of the described physical capacity lests in children with $C P$. The tests are valuable for rehabilitation research in groups of children with $C P$ (for example, evaluation of sports or physical therapy programmes). In clinical settings, however, one should be cureful when interpreting the test results.

It is evident that the measured variables are distinctly subnormal in most of the children with CP when compared with their healthy peers. Only three children 
with CP had test outcomes within the normal range. Possible explanations for this could be agonist/antagonist co-contraction, low muscle mass (especially of the fast-twitch fibres), the presence of contractures, detraining, and attention deficits.

Accepted for publication 2 nd January, 1996.

Acknowledgements

We thank all the children and their parents who participated in this study, and also Laudy Janssens and Yvonne Burggraaff for their help during data collection. We also thank the Children's Rehabilitation Centre Franciscusoord in Valkenburg and the Heilige Geest School in Maastricht for their co-operation in this study. The study was supported by the 'Moederstichting ter Behartiging van de Belangen van het Gebrekkige kind'.

Authors' Appointments

* Rita JG van den Berg-Emons, PhD;

Donnie $\mathrm{C}$ de Barbanson, MSc;

Department of Movement Sciences, University of Limburg, PO Box 616, 6200 MD Maastricht, The Netherlands.

Marleen A van Baak, PhD;

Wim HM. Saris, MD, Professor;

Department of Human Biology, University of Limburg, Maastricht, The Netherlands.

Lucianne Speth, MD, Children's Rehabilitation Centre Franciscusoord, Valkenburg a/d Geul.

*Correspondence to first author.

\section{SUMMARY}

Test-retest reliability of measurements of peak aerobic power (cycle ergometer), anaerobic power (cycle ergometer), and isokinetic muscle strength of the knee (Cybex) was established in 12 young children with cerebral palsy (spastic diplegia/tetraplegia; mean age 8.8 years) and in addition in 39 healthy controls (mean age 9.2 years). The cycle ergometer tests were found to be reliable in both the group with $\mathrm{CP}$ and the control group (test-retest correlations varying from 0.72 to 0.96 ). The isokinetic strength test in the group with CP was only reliable at $30 \%$, whereas in the control group high test-retest correlations were also found at $60^{\circ} / \mathrm{s}$ and $120 \% \mathrm{~s}$

\section{RÉSUMÉ}

Fidélité des tests de dêtermination de la puissante de pointe en aérobie et anaérobie, et de la force nusculaire isocinétique chez les enfants IMC ef les contrôles en bonne santé

La fidélité test-retest des mesures de puissance de pointe en aérobie (cycle ergométrique) et en anaërobie (cycle ergométrique), et la force musculaire isocinétique du genou (Cybex) chez 12 jeunes IMC à forme spastique, diplégique/tétraplégique (moyenne d'âge 8.8 ans) et chez 39 contrôles en bonne santé (moyenne d'âge 9.2 ans) Les tests d'ergométrie sur cycles se montrèrent fiables tant dans le groupe IMC que le groupe contrôle (corrélations test-retest variant entre 0.72 et 0.96 ). Le test de force isocinétique dans le groupe IMC ne fut fidèle qu'à $30 \%$, tandis que dans le groupe contrôle des corrélations test-retest élevées, à $60 \% \mathrm{~s}$ et $120 \% \mathrm{~s}$ étaient trouvées.

\section{ZUSAMMENFASSUNG}

Verlässlichkeit von Tesls zur Bestimmung von Peak Aerobic Power, Anaerobic Power und isokinetischer Muskelkraft im Knie bei Kindern mit Cerebralparese und gesunden Kontrollen Bei 12 Kindern mit Cerebralparese und spastischer Diplegie/Tetraplegie (mittleres Alter 8.8 Jahre) und bei 39 gesunden Kontrollen (mittleres Alter 9.2 Jahre) wurde die Test-retest Reliabilität von Messungen der Peak Aerobic Power (Fahrradergometer), der Anaerobic Power (Fahrradergometer) und der isokinetischen Muskelkraft im Knie (Cybex) untersucht. Die Fahrradergometer Tests erwiesen sich sowohl in der Gruppe mit Cerebralparese als auch in der Kontrollgruppe als verläßlich (Test-retest Korrelationen zwischen 0.72 und 0.96). Der isokinetische Krafttest war in der Gruppe mit Cerebralparese nur bei $30^{\circ} / \mathrm{s}$ verläßlich, während in der Kontrollgruppe hohe Test-retest Korrelationen bei $60 \% \mathrm{~s}$ und $120 \% \mathrm{~s}$ gefunden wurden.

\section{RESUMEN}

Fiabilidad de las pruebas para determinar el máximo de potencia aeróbica, anaeróbica y potencia muscular isoquinética, en niños con Parálisis Cerebral y en controles normales

Se establecieron pruebas y contrapruebas de fiabilidad de las mediciones del pico de potencia aeróbica (bicicleta ergométrica), anaeróbica (bicicleta ergométrica) y potencia muscular isoquinética de la rodilla (Cybex) en 12 niños con parálisis cerebral y diplegia-tetarplegia espástica (promedio de edad 8.8 años) y además en 39 controles sanos (edad promedio de 9.2 años). Se halló que lka bicicleta ergométrica constituia la prueba más fiable en el grupo con PC y en el control (las correlaciones prueba-contraprueba variaban de 0.72 a 0.96 ). La prueba de fuerza isoquinética en el grupo con $\mathrm{PC}$ constituia la prueba fiable solamente en $30 \%$, pero en el grupo control las correlaciones altas entre prueba y contraprueba se hallaron en $60 \% \mathrm{~s} \mathrm{y} 120 \% \mathrm{~s}$. 
Reforencess

Alexander J, Molnar GE. (1973) Muscular strength in children: preliminary report on objective standards. Archives of Physical Medicine and Rehabilitation 54: 42-47.

Bar-Or O. (198.3) Pedialric Sports Medicine for the Practitioner. From Physiologic Principles to Clinical Applications. New York: Springer Verling.

- (1986) Pathophysiological factors which limit the exercise capacity of the sick child. Medicine and So'ine ill Sports and Erercise 18: 276-82.

- (1987) The Wingate Anaerobic Test: an update on methodology, reliability and validity. Sports Modicine 4: $381-94$.

Berg K, Isaksson B. (1970) Body composition and nutrition of school children with cercbral palsy. Acia Paediatrica Seandinavica 204(suppl.): $4.1-69$

Binder H, Eng GD, (1989) Rehabilitation management of childeen with spastic diplegic cercbral malsy. Arrives of Pliysical Medicine and Rehabilitation 70: $48-19$

Brown A. (1975) Review: Physical fitness and cerebral palsy. Child: Care, Healh and Development I: $143-52$.

Cruickshank WM. (1966) Cerebral palsy. New York: Syracuse University Press.

CYBEX (1983) Cybex lsolated-Joint Testing and Elicretisc, a Handbouk for Using Cybex II and the U.B.X.T. Ronkonkoma, New York

Dotan R, Bar-Or O. (1980) Climatic heat stress and perlormance in the Wingate Anaerobic Test. European , lonmal of Applied Physiology 44: $2.37-4.3$.

Dresen MHW, Vermeulen H, Netelenbos BJ, Krot H. (1982) Physical work capacity and classroom atlention of handicapped and nonhandicapped chilatren. Intermational Jommal of Rehabilitation Re'searid 5: 5-12

(iamstorp) I. (1985) Pediatric Neturology. London: Butlerworths.

Gillian 'TB, Villanacei JF, Freedson PS, Sady SP. (1979) lsokinctic corcue in boys and girls ages 7 to 13: elfect of age, height and weight. Researd Ollar/(c) 50 : 50)

Ulislop H.J. Pertile J. $(1967)$ 'The isokinetic concept of exercise. Physical Therapy 47: 114-17.

Ingram TTS. (1966) The neurology of cerebral palsy. Archives of Disease in Childhood 41: 337-57.

Lundberg A. (1978) Maximal aerobic capacity of young people with spastic cerebral palsy. Developmental Medicine and Child Neurology 20. 205-10.

- (1984) Longitudinal study of physical working capacity of young people with spastic cerebral palsy. Developmental Medicine and Child Neurology 26: $328-34$.

Molnar GE, Alexander J, Gutfeld N. (1979)

Reliability of quantitative strength measurements in children. Archives of Physical Medicine and Rehabilitation 60: 218-21.

Olow I, Berg K. (1970) School children with cerebral palsy at Bräcke Östergård Pediatric Habilitation Centre. Acta Paediatrica Scandinarica 204(suppl.): 7-13

Parker DF, Carriere L, Hebestreit H, Bar-Or O (1992) Anaerobic endurance and peak muscle power in children with spastic cerebral palsy. American Journal of Diseases of Children 146: 1069-73.

Roede MJ, Wieringen van JC. (1985) Growth diagrams 1980. Netherlands third nationwide survey. Tijdschrift roor Sociale Gezondleeidszorg 63(suppl.): 134

Ruby DO, Matheny WD. (1962) Comments on growth of cerebral paisied children. Journal of the American Dietetic Association 40: 52-57.

Thistle HG, Hislop HJ, Moffroid M, Lowman EW. (1967) Isokinetic contraction: A new concept of resistive exercise. Archives of Physical Medicine and Rehabilitation 48: 279-82.

Tirosh E, Bar-Or O, Rosenbaum P. (1990) New muscle power test in neuromuscular disease. American Iournal of Diseases of Children 144: 1083-7.

Tobis JS, Saturen P, Larios G, Posniak AO. (1961) Study of growth patterns in cerebral palsy. Archives of Physical Medicine \& Rehabilitation 42: 475-81

Washington RL, Gundy van JC, Cohen C, Sondheimer HM, Wolfe RR. (1988) Normal aerobic and anaerobic exercise data for North American schoolage children. Joumal of Pediatrics 112: 223-33. 